Venturini, M.A.F.A.'; Ferro, D.G. ${ }^{2}$; Gioso, M.A $\mathrm{A}^{3}$

\section{3 - Displasia dental: múltiplas anomalias do desenvolvimento dental em cão. Relato de caso}

1- Médico Veterinário autônoma - Odontovet, São Paulo-SP

2- Pós-graduando da Faculdade de Medicina Veterinária e Zootecnia da Universidade de São Paulo, São Paulo-SP - Odontovet, São Paulo-SP

3- Departamento de Cirurgia da Faculdade de Medicina Veterinária e Zootecnia da Universidade de São Paulo, São Paulo-SP

Anomalias de desenvolvimento dental em cães são raras. Ainda assim, algumas destas têm sido descritas na literatura, individualmente. É dificil porém que se encontrem relatos de um conjunto de anomalias dentais associadas, ocorrendo em um mesmo animal. Dentre as anormalidades mais freqüentemente relatadas estão a impactação dental, erupção parcial, oligodontia, hipoplasia ou hipocalcificação de esmalte, hipoplasia de dentina, dens in dente, hipoplasia radicular. Tais afecções podem acometer tanto a dentição decídua como os dentes permanentes do cào. Dadas certas particularidades relacionadas à patofisiologia da maioria destas anormalidades, porém, observa-se uma maior ocorrência em dentes permanentes. Segundo relatos da literatura, dentes inclusos podem ocasionar o desenvolvimento de neoplasias malignas ou de formações benignas localmente agressivas. A causa da retenção de dentes tem sido associada a processos sistêmicos que provocam estresse, tais como a cinomose ou processos infecciosos graves. A oligodontia, ausência de um ou alguns dentes na cavidade oral, não é comumente observada em cães. Em geral, acomete pré-molares, especialmente primeiros pré-molares. Têm sido sugeridos fatores hereditários para esta anomalia e acredita-se que haja envolvimento de um gen autossômico recessivo anômalo na sua etiologia. A hipoplasia dental provoca alterações no desenvolvimento do esmalte e da dentina. Não obstante, estas anomalias podem surgir individualmente, como hipoplasia ou hipocalcificação de esmalte, ou ainda hipoplasia de dentina. Esta provoca o surgimento de dentes muito pequenos ou, mais freqüentemente, raízes diminutas. Este quadro está, em geral, associado a deficiências nutricionais crônicas, fatores infecciosos ou mesmo ao trauma. No presente relato, destacamos o atendimento, no Centro Odontológico Veterinário Odontovet $^{\mathbb{8}}$-SP, de um cão da raça Retriever do Labrador, fêmea, com 7 meses de idade que apresentava histórico de cinomose aos dois meses e meio de idade, tratada com sucesso. Ao exame clínico, apresentava parâmetros normais, sem qualquer relato de alterações sistêmicas atuais por parte do proprietário. A cavidade oral mostrou ausência de incisivos laterais superiores e inferiores, incisivo intermédios inferiores e superior esquerdo, incisivos centrais inferiores, caninos inferiores e superior direito, primeiro e segundo pré-molares inferiores, terceiro pré-molar superior direito, quarto pré-molares superiores e inferiores e segundo e terceiro molares inferiores; dentes parcialmente erupcionados: incisivo intermédio direito, primeiro e segundo pré-molares superiores, terceiro pré-molar superior esquerdo e canino superior esquerdo; dentes erupcionados e com malformações de esmalte: primeiro e segundo molares superiores; persistência do canino inferior direito decíduo. Dez dias depois, o animal foi anestesiado com Propofol $(10 \mathrm{mg} / \mathrm{kg})$ e Diazepan $(0,5 \mathrm{mg} / \mathrm{kg})$ e mantido com Propofol para exame radiográfico intra-oral minucioso. O exame revelou que todos os dentes ausentes no exame clínico estavam inclusos, com exceção dos segundo e terceiro molares inferiores direitos (agenesia). Todos eles se mostraram malformados e de tamanhos diminutos (hipoplasia dental). Os dentes que se apresentaram parcialmente erupcionados mostraram raizes aparentemente normais, porém de tamanho bastante reduzido (hipoplasia radicular). Os primeiros molares inferiores apresentaram comunicação com a polpa dental, porém o proprietário do animal optou pela exodontia em detrimento ao tratamento de canal radicular. Foi realizada exodontia dos quartos pré-molares superiores e do canino decíduo. Os dentes com malformação de esmalte foram submetidos a tratamento restaurador. Este caso mostra-se bastante interessante por reunir, em um mesmo animal, diversas malformaçòes relacionadas ao desenvolvimento dental. Achados como a hipoplasia de raiz e um número elevado de dentes não erupcionados não são comumente relatados na literatura especializada. De acordo com muitos artigos científicos, a grande maioria destas malformações está 
intimamente relacionada a alterações sistêmicas, tais como a cinomose apresentada neste relato de caso. Tanto este fator como o componente genético sugerido em alguns trabalhos, merecem ser mais estudados até que tenhamos certeza de seu papel na etiologia das malformações dentais.

\section{4 - Maloclusão em chinchilas}

Venceslau, A. '; Corrêa, H.L. ${ }^{\text {; }}$ Gioso, M.A. ${ }^{3}$
1- Médico Veterinário autônomo - Odontovet, São Paulo-SP

2- Mestre em Cirurgia da Faculdade de Medicina Veterinária e Zootecnia da Universidade de São Paulo, São Paulo-SP - Odontovet, São Paulo-SP

3- Departamento de Cirurgia da Faculdade de Medicina Veterinária e Zootecnia da Universidade de São Paulo, São Paulo-SP

Um dos problemas mais comuns encontrados em cavidade oral de chinchilas é a maloclusão. A origem deste tipo de distúrbio ainda não é totalmente conhecida, mas acredita-se que o fator hereditário e alterações no desgaste natural dos dentes possam estar relacionados. Este trabalho pretende demonstrar os principais tipos de maloclusões e as técnicas operatórias para correção das mesmas. Os animais acometidos apresentam perda de apetite, perda de peso, salivação intensa, mudança na forma de apreender e mastigar o alimento. $\mathrm{O}$ tratamento consiste na redução da coroa clínica dos dentes acometidos, ou até mesmo sua extração. As chinchilas (Chincbilla lanigera) pertencem à familia Chinchillidae e à ordem Rodentia. Estes roedores apresentam a seguinte fórmula dentária: $2 \mathrm{x}$ (I 1/1; C 0/0; PM 1/1; M 3/3), e são hipsodontes arradiculares, ou seja, apresentam todos os dentes com erupção contínua e tem a característica de não apresentarem estrutura radicular verdadeira, mas sim, coroa supragengival (coroa clínica) e coroa subgengival (raiz clínica), além de terem o ápice aberto. Devido ao crescimento contínuo dos dentes destes roedores, problemas de maloclusão podem originar lesòes e debilitaçào aos animais acometidos. A maloclusào pode ser $\mathrm{de}$ origem atraumática ou traumática. As maloclusões atraumáticas ocorrem por comprometimento genético ou alteraçōes no desgaste dos dentes. Quando há o envolvimento genético, os dentes antagonistas não ocluem de maneira adequada, e sem o correto contato e conseqüente abrasão entre eles, ocorre um crescimento excessivo dos dentes antagonistas ou da porção do dente que não sofre contato com o outro. Já nas maloclusões ocasionadas pelo desgaste insuficiente dos dentes, acredita-se que o fator dieta seja o principal motivo do distúrbio, cuja consistência ou forma inadequada dos alimentos podem não promover a abrasão suficiente para desgastar os dentes. Em ambos os casos, os dentes sofrem um crescimento irregular, levando à formação de pontas dentárias ou desnivelamento do plano oclusal. Essas pontas dentárias ocorrem com maior freqüência na face vestibular dos dentes superiores, levando a lesões em mucosa jugal, muitas vezes ulceradas, e nos dentes inferiores, quando ocorrem, sào mais freqüentes na face lingual, levando até mesmo ao encarceramento da língua, ventral ou dorsalmente. As maloclusões traumáticas ocorrem por perda ou fratura de elemento dental, e conseqüentemente o crescimento excessivo do dente antagonista. Os sinais clínicos apresentados são perda de peso, inapetência, salivação intensa, dificuldade em apreender ou mastigar o alimento. $\mathrm{O}$ tratamento consiste na redução da coroa clínica, que é feita através de desgaste das pontas dentárias e ajuste oclusal com fresas ou brocas em peça de mão ou baixa rotação com peça reta, ou redução de coroa clínica quando o problema for nos incisivos. Deve-se tomar bastante cuidado para não lesar tecidos moles, usando afastadores de bochecha e abaixadores de língua apropriados. Outra opçào para tratamento, porém pouco usual devido às dificuldades anatômicas, consiste na exodontia do dente acometido, no entanto, deve-se levar em conta o crescimento do dente antagonista, que em alguns casos também deve ser extraído. Indica-se como pós-operatório a administração de analgésicos/ antiinflamatórios e higienização com anti-sépticos orais, além de, eventualmente, se fazer hidratação e alimentação forçadas. O proprietário também deve estar ciente de que provavelmente haverá recidiva, e que deverá ficar atento aos sinais e fazer retornos freqüentes para reavaliação e tratamento. 